\title{
Involvement of PPAR $\alpha$ in the growth inhibitory effect of arachidonic acid on breast cancer cells
}

\author{
Claudia Bocca*, Francesca Bozzo, Germana Martinasso, Rosa Angela Canuto and Antonella Miglietta \\ Department of Experimental Medicine and Oncology, University of Torino, C. Raffaello 30, 10125 Torino, Italy \\ (Received 31 July 2007 - Revised 17 January 2008 - Accepted 18 January 2008 - First published online 28 February 2008)
}

Epidemiological studies suggest that dietary PUFA may influence breast cancer progression. $n-3$ PUFA are generally known to exert antitumour effects, whereas reports relative to $n$-6 PUFA anti-carcinogen effects are controversial. Arachidonic acid (AA; 20:4n-6) and its metabolites have been shown to inhibit the growth of human breast cancer cell lines, even if the downstream mechanisms by which AA may influence carcinogenesis remain unresolved. We explored the molecular basis for AA influence on proliferation, signal transduction and apoptosis in two human breast cancer cell lines, MCF-7 and MDA-MB-231. In both cell lines AA inhibited cell growth in a dose-dependent manner, even if MDA-MB-231 was somewhat more growth-inhibited than MCF-7. AA decreased extracellular signal-regulated protein kinase 1/2 phosphorylation level, and positively modulated PPAR $\gamma$ and PPAR $\alpha$ expression, with only a slight effect against PPAR $\beta / \delta$. In addition, AA increased Bak (an apoptosis-regulating protein) expression and reduced procaspase-3 and -9 levels only in MDA-MB-231 cells, thus indicating that the growth inhibitory effect can be correlated with apoptosis induction. In both cell lines the use of a specific antagonist made it possible to establish a relationship between AA growth inhibitory effect and PPAR $\alpha$ involvement. AA decreases cell proliferation most likely by inducing apoptosis in MDA-MB-231 cells, while in the MCF-7 cell line the growth inhibitory activity can be attributed to the inhibition of the signal transduction pathway involved in cell proliferation. In both cases, the results here presented suggest PPAR $\alpha$ as a possible contributor to the growth inhibitory effect of AA.

Arachidonic acid: Breast cancer cells: PPAR: Extracellular signal-regulated protein kinase: Apoptosis

Breast cancer still represents one of the most relevant mortality factors in women throughout the world, despite the significant advancements in its early detection and therapeutic approaches. Some evidence has established dietary essential fats as potential regulators of breast tumour cell growth ${ }^{(1,2)}$. It is known that $n-3$ and $n-6$ fatty acids, the two major families of essential fatty acids, play an important role in tumour proliferation, though their bio-clinical mechanisms on tumour cells are still not properly understood ${ }^{(2-4)}$. n-6 Fatty acids were found to stimulate the growth and metastasis of human breast cancer cells ${ }^{(5,6)}$, while $n-3$ fatty acids appeared to exert a protective effect ${ }^{(7)}$. More recently, it has been reported that both $n-3$ and $n-6$ PUFA are able to reduce the growth of different human cancer cells, although to different extents ${ }^{(8)}$.

Literature data suggest that the intake of PUFA may modulate cell behaviour and growth by a variety of mechanisms, including modification of tumour cell membranes which, in turn, can affect cell signalling pathways, lipid peroxidation and oxidative stress ${ }^{(9)}$, eicosanoid production, fatty acid metabolism ${ }^{(10)}$ and regulation of gene expression ${ }^{(11)}$.

Among n-6 PUFA, 20:4n-6 arachidonic acid (AA) is a relatively minor PUFA found in cell membrane glycerolipids ${ }^{(12)}$, which has been reported to inhibit the growth of some breast cancer cell lines ${ }^{(4)}$. In contrast to other more abundant unsaturated fatty acids (linoleic or linolenic acid), levels of unesterified AA are stringently controlled within mammalian cells, and the pathways of AA uptake, incorporation and remodelling are well documented ${ }^{(13)}$. The intracellular levels of AA are regulated through distinct and non-overlapping mechanisms. In resting cells, low concentrations of AA are tightly maintained by basal levels of rapid catabolism, by membrane glycerolipid recycling ${ }^{(14)}$ and by esterification ${ }^{(15)}$. On the other hand, a stimulus-induced release of AA by cytosolic phospholipase $2 \alpha$ results in its rapid metabolism induced by cyclooxygenase-2, thereby limiting the intracellular AA pools ${ }^{(14)}$.

Once released from the membrane, AA and its metabolites are important signals that regulate a wide variety of cellular functions ${ }^{(16)}$. The range of biological processes in which AA and its metabolites participate is vast; they regulate the transcription of several families of genes including heat-shock-protein genes $^{(17)}$, genes involved in cell-cycle control ${ }^{(18)}$, inflammation $^{(19)}$, steroid biosynthesis ${ }^{(20)}$ and proto-oncogenes ${ }^{(21,22)}$.

There are several other mechanisms probably implied in AA effects, not to be considered mutually exclusive, such as mechanisms implied in AA-induced apoptosis. In this regard, it has been reported that AA-induced apoptosis is transcriptionally dependent and involves the regulation of the key families of genes involved in cell survival and apoptosis.

Abbreviations: AA, arachidonic acid; DMEM, Dulbecco's modified Eagle's medium; ER, oestrogen receptor; ER $\alpha(+)$ and ER $\alpha(-)$, well differentiated and poorly differentiated ER $\alpha$ cells respectively; ERK, extracellular signal-regulated protein kinase; Tris, Tris(hydroxymethyl) amino methane.

* Corresponding author: Dr C. Bocca, fax +390116707753, email claudia.bocca@unito.it 
For example, an alternate downstream target of unesterified intracellular AA is ceramide signalling of apoptosis initiated via the TNF- $\alpha$ pathway ${ }^{(23)}$, since cancer cells treated with exogenous $\mathrm{AA}$ at concentrations that induce apoptosis accumulate ceramide ${ }^{(24)}$. It has been reported that exogenous AA and inhibitors of AA metabolism that lead to the accumulation of unesterified AA are cytotoxic to the colon cancer cell line ${ }^{(8)}$. Of interest is the observation that AA induced the suppression of the growth of different cancer cells through a mechanism that involves lipid peroxidation and PPAR activation $^{(25)}$.

PPAR are transcription factors with a pivotal role in lipid metabolism and homeostasis ${ }^{(26)}$; they function by forming heterodimers with the retinoid $X$ receptor ${ }^{(27,28)}$. There are three PPAR subtypes $(\alpha, \beta$ and $\gamma)$ which bind to different ligands, among them fatty acids and their metabolites, so regulating the expression of genes involved in lipid transport and metabolism within the cell. In mammals, PPAR $\alpha$ is most highly expressed in brown adipose tissue, followed by liver, kidney, and heart. Activation of rat liver PPAR $\alpha$ provides an anti-apoptotic mechanism ${ }^{(29)}$. PPAR $\beta$ is expressed in all tissues studied to date ${ }^{(30)}$, whereas PPAR $\gamma$ is highly expressed in adipose tissue, as well as in muscle, colon, and liver. The importance of PPAR activation in preventing epithelial carcinogenesis is evident in different tumour systems. Activation of PPAR $\gamma$ through troglitazone and other PPAR $\gamma$ activators causes the inhibition of proliferation and the induction of apoptosis, both in vitro and in vivo ${ }^{(31)}$. PPAR can mediate inflammation, and this effect is potentiated by elements from AA metabolic pathways. These include leukotriene $B_{4}$, derived from the lipoxygenase pathway, and 15-deoxy$\Delta^{12,14}$-prostaglandin $\mathrm{J}_{2}$, related to the cyclooxygenase pathway. 15-Deoxy- $\Delta^{12,14}$-prostaglandin $J_{2}$ is a PPAR $\gamma$ activator that has been shown to counteract the effects of the proinflammatory cytokines TNF $\alpha$, IL-1, and IL-6 $6^{(32)}$.

Eicosanoids and a range of fatty acids, such as the PUFA linoleic acid and AA, bind to PPAR at physiological concentrations and regulate gene transcription ${ }^{(33)}$. Furthermore, all three PPAR subtypes have been implicated in carcinogenesis $^{(34)}$ and it is known that PPAR signalling can influence cell survival and apoptosis ${ }^{(35)}$. The objective of the current study was to understand the potential mechanisms of action of AA modulation of breast cancer cell growth; for this purpose, we compared the influence of AA on proliferation, signal transduction and apoptosis in two breast cancer cell lines, the well differentiated oestrogen receptor $($ ER $) \alpha(+)$ MCF-7 cells and the poorly differentiated $\operatorname{ER} \alpha(-)$ MDAMB-231 cells. In particular we focused our attention on the interaction between the AA and PPAR pathways, an interaction that could provide an opportunity to develop drug combinations that maximize growth arrest and apoptosis in breast cancer cells.

\section{Materials and methods}

\section{Antibodies and chemicals}

MDA-MB-231 and MCF-7 breast cancer cell lines were a kind gift from Professor Sebastiano Andò, Department of Pharmaco-Biology, Faculty of Pharmacy, University of Calabria, Cosenza, Italy. AA, PPAR $\alpha$ antagonist (MK886), PPAR $\gamma$ antagonist (GW9662), culture media, mouse monoclonal antibody specific to $\beta$-actin and chemicals were purchased from Sigma Chemical (MO, USA). Cell culture plasticware was from TPP (Trasadingen, Switzerland). Rabbit polyclonal antibody specific for PPAR $\alpha$ (sc-9000), PPAR $\beta$ (sc-7197), PPAR $\gamma$ (sc-7196), Bak (sc-832), Bcl-2, caspase-3 (sc-7148), caspase-9p10 (sc-7885), caspase-8p20 (sc-7890) and for extracellular signal-regulated protein kinase (ERK)1 (sc-94), mouse monoclonal antibody specific for phospho-ERK1/2 (sc-7383), goat anti-rabbit (sc-2004) and anti-mouse (sc-2005) secondary antibodies were obtained from Santa Cruz Biotechnology (CA, USA). The enhanced chemiluminescence detection system was from Amersham Pharmacia Biotech (Uppsala, Sweden). The protein assay kit and $\mathrm{iQ}^{\mathrm{TM}} \mathrm{SYBR}^{\circledR}$ Green SuperMix Bio-Rad were from Hercules (CA, USA). The RNeasy Mini $\mathrm{Kit}^{\circledR}$ was from QIAGEN (GmbH, Germany); the cDNA Archive kit was from Applied Biosystems (Foster City, CA, USA).

\section{Cell culture}

MDA-MB-231 and MCF-7 breast cancer cells were grown in DMEM (Dulbecco's modified Eagle's medium) supplemented with $10 \%$ foetal bovine serum, $100 \mathrm{U}$ penicillin/ml, $100 \mu \mathrm{g}$ streptomycin $/ \mathrm{ml}$ and $25 \mu \mathrm{g}$ amphotericin $\mathrm{B} / \mathrm{ml}$. Cells were cultured at $37^{\circ} \mathrm{C}$ in a humidified incubator with $5 \% \mathrm{CO}_{2}$ and $95 \%$ air and regularly examined using an inverted microscope. For treatments, cells were seeded at a density of $3 \times 10^{4}$ cells/ $\mathrm{cm}^{2}$ and cultured for $24 \mathrm{~h}$ to allow them to adhere to the substratum. The medium was then replaced with serum-free DMEM supplemented with $100 \mathrm{U}$ penicillin/ml and $100 \mu \mathrm{g}$ streptomycin $/ \mathrm{ml}, 25 \mu \mathrm{g}$ amphotericin $\mathrm{B} / \mathrm{ml}, 2 \mathrm{~mm}$ glutamine, $1 \%$ ITS (insulin-transferrin-sodium selenite), $1 \%$ vitamin solution, $0.4 \%$ serum bovine albumin (fatty acid free) and AA. AA was dissolved in foetal bovine serum and the concentration of foetal bovine serum was adjusted so it was the same in all experiments and the final concentration was no stronger than $0.01 \%$ $(\mathrm{v} / \mathrm{v})$. Control groups received the same amount of foetal bovine serum. When GW9662 (PPARy antagonist) and MK886 (PPAR $\alpha$ antagonist) were used, they were added to the medium $1 \mathrm{~h}$ before AA treatment. GW9662 is an irreversible PPAR $\gamma$ antagonist, identified in a competition-binding assay against the human ligand-binding domain; it binds PPAR $\gamma$ and covalently modifies a cystein residue in the ligand binding site of PPAR $\gamma^{(36)}$. MK886 inhibits PPAR $\alpha$ by a non-competitive mechanism; it prevents the conformational change necessary for PPAR $\alpha$ ligand-receptor interaction ${ }^{(37)}$.

\section{Viability and growth rate determination}

The exponentially growing cells were harvested with $0.25 \%$ trypsin-0.02\% EDTA treatment and seeded in twelve-well culture plates. After overnight incubation to allow cell attachment, the medium was removed and replaced with fresh serum-free DMEM containing AA at a series of concentrations with or without $5 \mu \mathrm{M}$ GW9662 or MK886. Viability and cell number were determined using the trypan blue $(0.5 \%$ in $\mathrm{NaCl}$ ) exclusion assay. Briefly, treated cells were washed with PBS and trypsinized. Aliquots of cell suspension $(100 \mu \mathrm{l})$ were incubated with the same volume of trypan blue for $5 \mathrm{~min}$. Finally, cells were transferred to the Bürker 
chamber and counted by a light microscope. Dead cells were defined as those stained with the dye. Samples were measured in three replicates and each experiment was repeated at least three times.

\section{Lactate dehydrogenase assay}

Cells were seeded in twelve-well-culture plates and appropriately treated. After treatment, the cell supernatant was collected for the measurement of lactate dehydrogenase release. The lactate dehydrogenase activity was determined spectrophotometrically by an assay based on the oxidation of $\mathrm{NADH}$ and the rate of decrease in absorbance at $340 \mathrm{~nm}$. The activity of lactate dehydrogenase was calculated as nanomoles of NADH consumed per ml per min. Samples were measured in three replicates and each experiment was repeated at least three times.

\section{Analysis of nuclear morphology}

Cells were plated on glass slides in twelve-well plates and appropriately treated. Changes in nuclear morphology were labelled by $4^{\prime}, 6$-diamidino-2-phenylindole and examined by fluorescent microscopy. The cells were fixed with $95 \%$ icecold ethanol for $5 \mathrm{~min}$ and incubated with $4^{\prime}, 6$-diamidino-2phenylindole $\left(1 \mathrm{mg} / \mathrm{ml}\right.$ in methanol) for $30 \mathrm{~min}$ at $37^{\circ} \mathrm{C}$ in the dark, then nuclear morphology was observed under a fluorescence microscope equipped with a UV light filter. Cells which exhibited reduced nuclear size, intense fluorescence, chromatin condensation and nuclear fragmentation were considered as apoptotic. Each experiment was repeated at least three times.

\section{Protein extraction and Western blotting}

Cells were seeded in $75 \mathrm{~cm}^{2}$ plates and then appropriately treated. Collected cells were suspended in lysis buffer containing $20 \mathrm{~mm}$ Tris(hydroxymethyl) amino methane (Tris) $-\mathrm{HCl}$ (pH 7.4), $150 \mathrm{~mm} \mathrm{NaCl}, 5 \mathrm{~mm}$ EDTA, 0.1 mM phenylmethyl-sulfonyl fluoride, $0.05 \%$ aprotinin, $0.1 \%$ Igepal and then incubated for $30 \mathrm{~min}$ at $4^{\circ} \mathrm{C}$. The suspension was centrifuged for $25 \mathrm{~min}$ at $12000 \mathrm{rpm}$, and the supernatant from this centrifugation was saved as total extracts. Protein contents in supernatants were measured using a commercially available assay (Biorad) with bovine serum albumin as a standard.

Equal amounts of proteins $(60 \mu \mathrm{g} /$ well $)$ were mixed with a solubilization buffer containing $250 \mathrm{~mm}$ Tris, $\mathrm{pH} 8 \cdot 8,4 \%$ SDS, $16 \%$ glycerol, $8 \%$ 2-mercaptoethanol and $0.1 \%$ bromophenol blue, and then fractionated by electrophoresis on SDS-PAGE. Proteins were transferred onto nitrocellulose for $2 \mathrm{~h}$ in a Biorad electroblotting device. Nitrocellulose matrices were blocked with $5 \%$ milk in TBST $(1 \mathrm{M}$ Tris buffer, $\mathrm{pH} 7 \cdot 4,5 \mathrm{M} \mathrm{NaCl}, 0.1 \%$ Tween-20) for $1 \mathrm{~h}$ at room temperature. For immunodetection, matrices were incubated overnight at $4^{\circ} \mathrm{C}$ with a primary antibody. The matrices were then detected by incubation for $1 \mathrm{~h}$ at room temperature with the corresponding horseradish peroxidase-conjugated secondary antibody. The immunoreactive bands were visualized using the enhanced chemiluminescence system. Band intensities were quantified by densitometry and the expression of proteins was reported as a proportion of $\beta$-actin or ERK1 protein expression to control for any discrepancies in gel loading. Fold change $v$. control values were calculated by normalizing densitometric values obtained from the various proteins with those obtained for $\beta$-actin or ERK1 (VersaDoc Imaging System 3000, Biorad). Each experiment was repeated at least three times.

\section{Evaluation of PPAR $\alpha$ expression by real-time PCR}

Total RNA was extracted using RNeasy Mini Kit ${ }^{\circledR}$. Real-time PCR was performed using single-stranded cDNA prepared from total RNA $(1 \mu \mathrm{g})$ with a High Capacity cDNA Archive kit. Forward and reverse primers were designed using Beacon Designer software (Bio-Rad, Hercules, CA) (see Table 1).

A PCR mixture $(25 \mu \mathrm{l})$, containing cDNA template equivalent to $80 \mathrm{ng}$ total RNA, 5 pmole each of the forward and reverse primers and $2 \times \mathrm{iQ}^{\mathrm{TM}} \mathrm{SYBR}^{\circledR}$ Green SuperMix, were amplified using an iCycler PCR (Bio-Rad, Hercules, CA). Each sample was tested six times and the threshold cycle (Ct) values were the corresponding mean. The fold change was defined as the relative expression compared to that at time 0 (time of seeding cells), calculated as $2^{-\Delta \Delta \mathrm{Ct}}$, where $\Delta \mathrm{Ct}=\mathrm{Ct}_{\text {sample }}-\mathrm{Ct}_{\mathrm{GAPDH}}$ and $\Delta \Delta \mathrm{Ct}=\Delta \mathrm{Ct}_{\text {sample }}-\Delta \mathrm{Ct}_{\text {time } 0}$.

\section{Statistical analysis}

Differences between the means were analysed for significance using the one-way ANOVA test with the Bonferroni post hoc multiple comparisons used to assess the differences between independent groups. All values are expressed as means with standard deviation, and differences were considered significant at $P<0.05$.

\section{Results}

\section{Cell viability}

To assess the effect exerted on human breast cancer cell proliferation, MCF-7 and MDA-MB-231 cancer cells were treated with increasing concentrations $(1-50 \mu \mathrm{M})$ of AA. Cell viability was examined by the trypan blue assay, which provides a direct count of cells that exclude the trypan blue dye, including apoptotic cells. Twenty-four-hour AA treatment remarkably decreased the survival of both cell lines in

Table 1. Primer design (FW, forward primer and RV, reverse primer) for evaluation of PPAR $\alpha$ expression by real-time PCR

\begin{tabular}{|c|c|c|c|}
\hline $\begin{array}{l}\text { Gene access } \\
\text { number }\end{array}$ & Sequence & $\begin{array}{c}\text { Annealing } \\
\left({ }^{\circ} \mathrm{C}\right)\end{array}$ & Cycles \\
\hline GAPDH & $\begin{array}{l}\text { FW: } 5^{\prime}-\text { GTC GGA GTC } \\
\text { AAC GGA TTT GG-3' }\end{array}$ & 52 & 30 \\
\hline NM_002046 & $\begin{array}{c}\text { RV: } 5^{\prime}-G G G \text { TGG AAT CAT } \\
\text { ATT GGA ACA TG-3' }\end{array}$ & & \\
\hline $\operatorname{PPAR} \alpha$ & $\begin{array}{c}\text { FW: } 5^{\prime}-\text { GGA TGT CAC ACA } \\
\text { ACG CGA TT-3' }\end{array}$ & 52 & 35 \\
\hline NM_005036 & $\begin{array}{c}\text { RV: } 5^{\prime} \text {-GCC AGA GAT TTG } \\
\text { AGA TCT GCA GTT-3' }\end{array}$ & & \\
\hline
\end{tabular}


a dose-dependent manner (Fig. 1), with a strong inhibitory effect against MDA-MB-231 cells (50\% inhibition with $50 \mu \mathrm{M}$ AA). Thus, compared with the well-differentiated MCF-7 cells (Fig. 1 (A)), the poorly differentiated MDAMB-231 cells (Fig. 1 (B)) appeared to be more susceptible to the AA growth inhibitory effect.

The growth-inhibitory effect of AA is accompanied by a cytotoxic side effect detected as the cell release of lactate dehydrogenase in the culture media (Fig. 2). In MCF-7 cells, the release is significantly increased at all the concentrations of AA used (Fig. 2 (A)), while in MDA-MB-231 cells the release is significantly augmented only with high concentrations of AA, with a maximal effect at $50 \mu \mathrm{M}$ dose (Fig. 2 (B)).

The most effective condition in inhibiting cell survival in both cell lines was obtained after $24 \mathrm{~h}$ treatment with $50 \mu \mathrm{M}$ $\mathrm{AA}$, so we used this experimental protocol for further experiments.

\section{Apoptosis induction}

To assess whether the decrease of cell growth by AA treatment was due to the induction of apoptosis, we further evaluated the effects of AA on the expression of apoptosisregulating proteins such as $\mathrm{Bak}, \mathrm{Bcl}-2$ (Fig. 3) and procaspase-3, -8 and -9 (Fig. 4).

In MCF-7 cells the inhibition of cell growth did not correlate with apoptosis induction, as AA caused a decrease in the content of the pro-apoptotic protein Bak concomitantly to an increase of the anti-apoptotic protein Bcl-2 (Fig. 3 (A)). On the contrary, a pro-apoptotic effect was detected in MDA-MB-231 (Fig. 3 (B)), in which AA induced a significant increase in the expression of Bak without any effect on the anti-apoptotic protein Bcl-2, which was expressed at basal condition. In addition, in MCF-7 cells AA did not modify the levels of procaspase- 8 and -9 (Fig. 4 (A)); in this cell line procaspase- 3 was undetectable, since the caspase- 3 gene is not expressed $^{(38)}$. In MDA-MB-231 (Fig. 4 (B)), AA induced a strong decrease of procaspase- 3 and -9 levels, suggesting that the cleavage of the proteins to the active form (caspase- 3 and -9) also occurred. The fact that in this cell line expression of procaspase- 8 was not modified seems to exclude the activation of extrinsic pathways of apoptosis.

In MDA-MB-231 cells evidence of apoptosis was confirmed by the analysis of nuclear morphology by staining with specific DNA fluorochrome 4',6-diamidino-2-phenylindole, which showed nuclear fragmentation and condensation above all after $24 \mathrm{~h}$ treatment with AA at $1 \mu \mathrm{M}$ concentration (Fig. 5 (B)).

Involvement of extracellular signal-regulated protein kinasemitogen activated protein kinase pathway

In an attempt to explore the nature of the antiproliferative response exhibited by MCF-7 and MDA-MB-231 cells, we analyzed the AA effect on the ERK-mitogen-activated protein kinase signal transduction pathway, a large network of signalling molecules regulating cell growth and differentiation (Figs. 6 and 7).

In MCF-7 cells $24 \mathrm{~h}$ treatment with AA caused a dosedependent decrease of phospho-ERK expression (active form), with the highest magnitude of reduction at $50 \mu \mathrm{M}$ concentration (Fig. 6 (A)).

The analysis of the short-time effect $(1,4,8$ and $16 \mathrm{~h})$ of $50 \mu \mathrm{M}$ AA on phospho-ERK level (Fig. 6 (B)) indicated a significant reduction of the ERK phosphorylation state starting from $8 \mathrm{~h}$ treatment. Also in MDA-MB-231 cells $24 \mathrm{~h}$ treatment with AA induced a strong decrease of phospho-ERK level, in this case the maximal downregulatory effect was observed at $25 \mu \mathrm{M}$ concentration (Fig. 7 (A)). The short-time analysis of the AA effect in this case indicated a reduction of phosphoERK from $8 \mathrm{~h}$ from the start of treatment (Fig. 7 (B)).

\section{PPAR expression}

Effects on PPAR expression were further examined to study the AA influence on mechanisms involved in cell growth regulation. We examined changes in the protein contents of different PPAR isoforms by western blot analysis. As shown in Fig. 8, 24h treatment with AA dose-dependently enhanced PPAR $\alpha$ expression in both cell lines. Also the PPAR $\gamma$ level was up-regulated by AA, which was more effective in MCF-7 cells. On the contrary, after AA treatment the PPAR $\beta$ level did not display substantial changes in MCF-7 cells and increased only slightly in MDA-MB-231 cells.

To evaluate whether AA could be directly responsible for the induction of PPAR $\alpha$ and $\gamma$, we also analysed its effects in the presence of a specific PPAR $\alpha$ (MK886) and PPAR $\gamma$ (GW9662) antagonist. Both antagonists were administered to MCF-7 and MDA-MB-231 cells at $5 \mu \mathrm{M}$ concentration, chosen on the basis of the existing literature ${ }^{(37,39)}$. As shown in Fig. 9 ((A) and (B)), in both cell lines pre-treatment $(1 \mathrm{~h})$
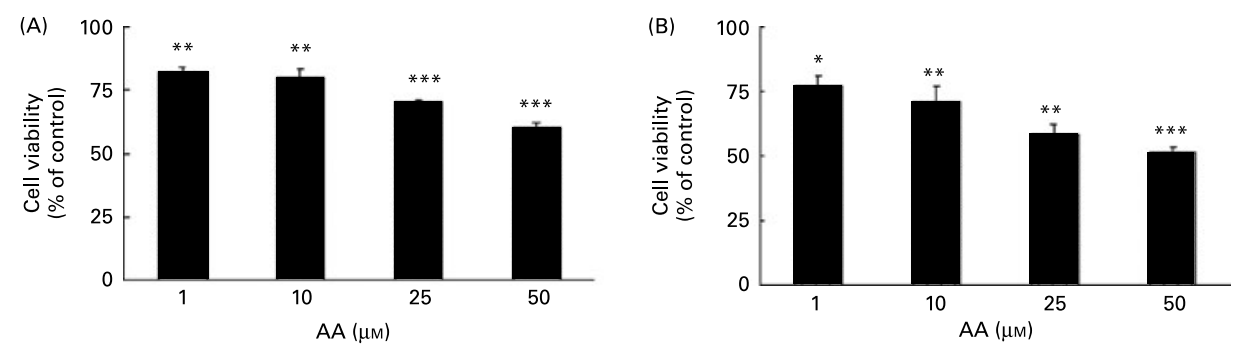

Fig. 1. Arachidonic acid (AA)-related growth inhibition of MCF-7 (A) and MDA-MB-231 (B) breast cancer cells. Cells were incubated with different concentrations of $\mathrm{AA}(1-50 \mu \mathrm{M})$ for $24 \mathrm{~h}$ and viability was determined by the trypan blue exclusion test. Values are presented as the percentage of control, with standard deviation shown by vertical bars, from three independent experiments conducted in triplicate. Mean values were significantly different from controls: ${ }^{\star} P<0.05$, ${ }^{\star \star} P<0.01$, ${ }^{* * \star} P<0.001$ 

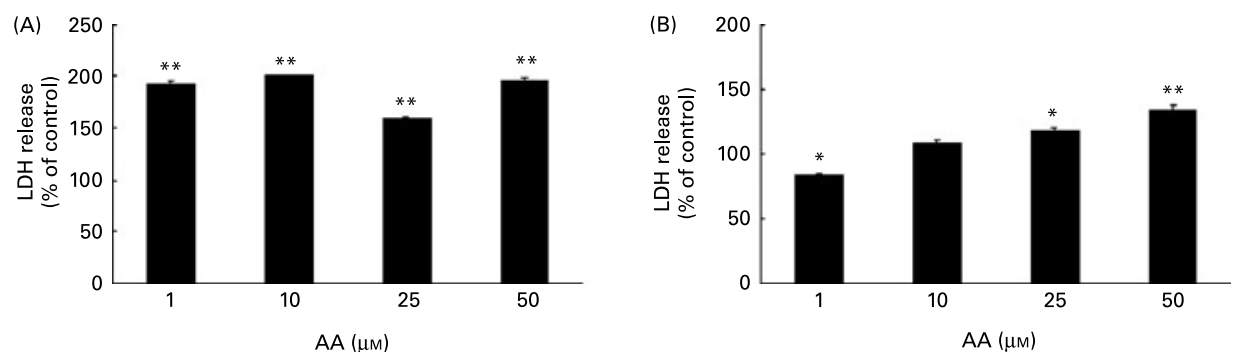

Fig. 2. Cytotoxic activity of arachidonic acid (AA). MCF-7 (A) and MDA-MB-231 (B) breast cancer cells were treated with different concentrations of $A A(1-50 \mu M)$ for $24 \mathrm{~h}$, then supernatants were collected for measurement of lactate dehydrogenase (LDH) amounts. LDH release is expressed as the percentages of nmoles of $\mathrm{NADH}$ consumed per $\mathrm{ml}$ per min. Values are means with standard deviation shown by vertical bars, from three independent experiments conducted in triplicate. Mean values were significantly different from controls: ${ }^{\star} P<0.05,{ }^{\star \star} P<0.01$.

with MK886 prevented an AA stimulatory effect on PPAR $\alpha$ expression; on the contrary, GW9662 was not able to influence AA effects on PPAR $\gamma$ expression (data not shown).

MCF-7 (Fig. 10 (A)) and MDA-MB-231 (Fig. 10 (B)) cells were cultured with AA, with or without $1 \mathrm{~h}$ pre-incubation with MK886, for $24 \mathrm{~h}$ and analysed by real-time PCR for subsequent changes in the PPAR $\alpha$ mRNA expression levels relative to control cells. In both cell lines PPAR $\alpha$ mRNA level increased after short time incubation with AA (data not shown) and declined below baseline level at $24 \mathrm{~h}$, when PPAR $\alpha$ protein amount was higher than control cells. The pre-treatment of the cells with the antagonist, alone or in the presence of AA, caused in both cases the increase of PPAR $\alpha$ mRNA level.

The effect of the antagonist can probably be related to the fact that it binds to PPAR $\alpha$ protein, thus preventing the

(A)

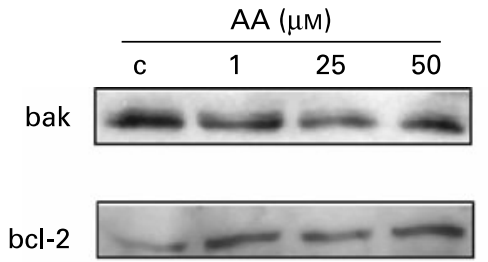

$\beta$-Actin

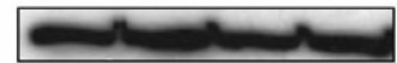

(B)

conformational change necessary for PPAR $\alpha$ ligand-receptor interaction $^{(37)}$

Involvement of PPAR $\alpha$ in cell proliferation, extracellular signal-regulated protein kinase-mitogen activated protein kinase pathway and apoptosis

To thoroughly evaluate whether AA-induced cell growth inhibition may be ascribed to PPAR $\alpha$ activation, the growth inhibitory effects of AA in MCF-7 and MDA-MB-231 cells were compared to those obtained in the presence of the specific antagonist MK886. As shown in Fig. 9 ((C) and (D)), in both cell lines the reduction of cell growth induced by AA was significantly prevented by MK886 administration, thus confirming the involvement of PPAR $\alpha$ in AA growth inhibitory activity.

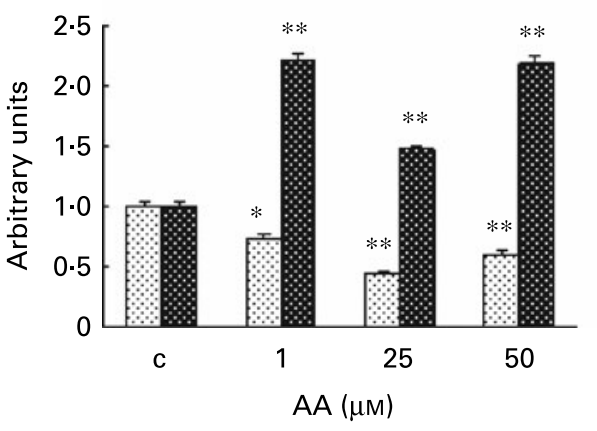

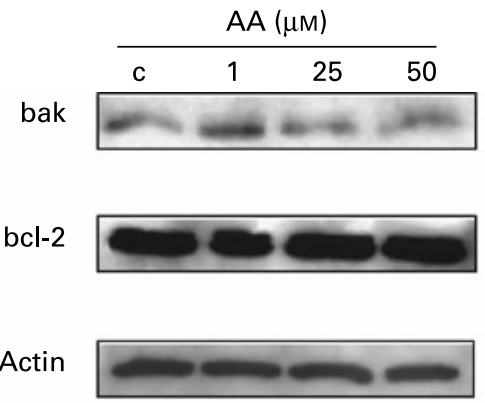

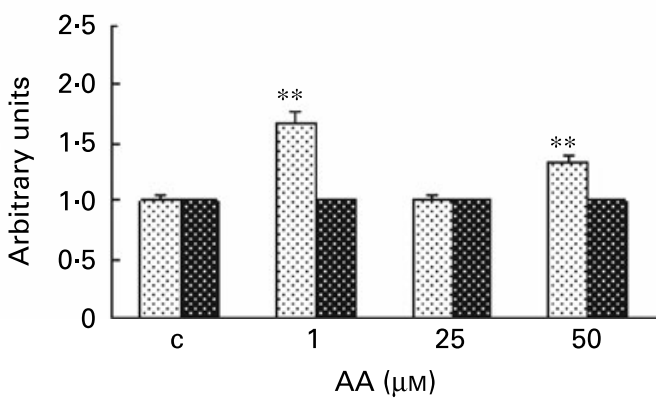

Fig. 3. Effect of arachidonic acid (AA) on pro- and anti-apoptotic proteins. MCF-7 (A) and MDA-MB-231 (B) breast cancer cells were incubated with 1,25 or $50 \mu \mathrm{M}$ AA for $24 \mathrm{~h}$, and total cell lysates were separated on $10 \%$ SDS-PAGE gel, transferred to nitrocellulose membrane and probed with anti-bak ( $\square$ ) or anti-bcl-2 (田) antibody. Protein contents were normalized by probing the same membrane with anti- $\beta$-actin antibody. The densitometric values of the bands are shown as means with standard deviation indicated by vertical bars, from three independent experiments. Mean values were significantly different from controls (c): ${ }^{\star} P<0.05$, ${ }^{* *} P<0.01$. 
(A)

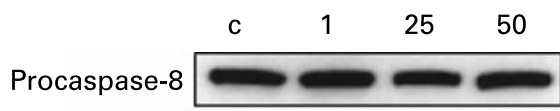

Procaspase-9

$\beta$-Actin
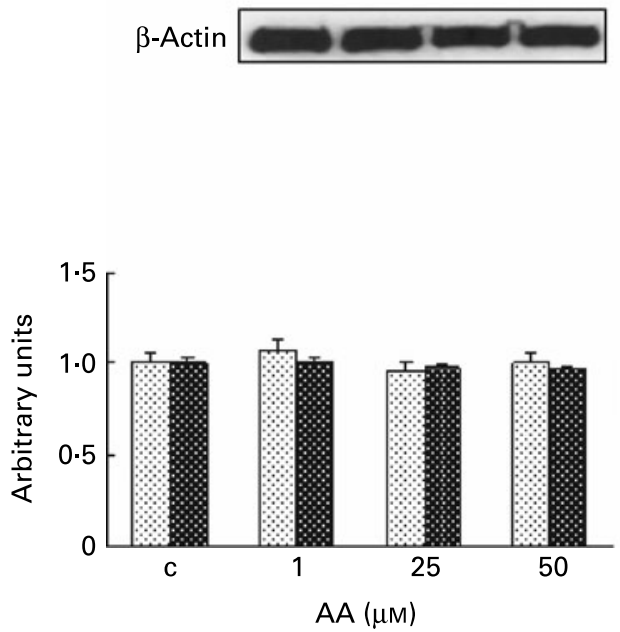

(B) AA ( $\mu \mathrm{M})$

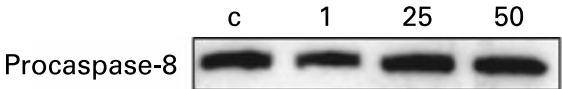

Procaspase-9

Procaspase-3

$\beta$-Actin
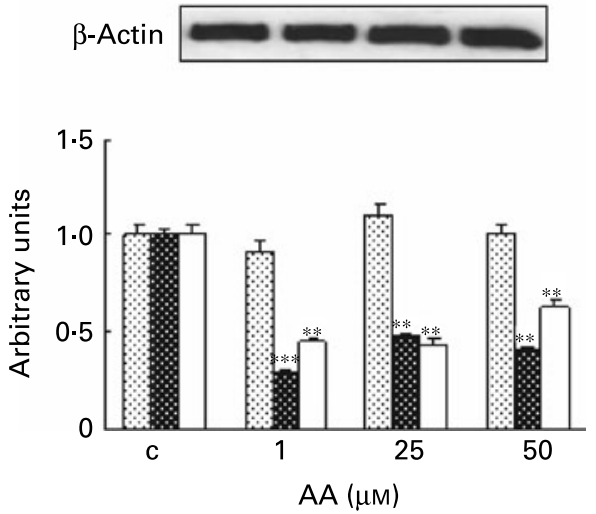

Fig. 4. Effect of arachidonic acid (AA) on procaspase-8, -9 and -3 . MCF-7 (A) and MDA-MB-231 (B) breast cancer cells were incubated with 1, 25 or $50 \mu \mathrm{M} A \mathrm{~A}$ for $24 \mathrm{~h}$, and total cell lysates were separated on $10 \%$ SDS-PAGE gel, transferred to nitrocellulose membrane and probed with an anti-caspase-8p20 (回), anti-caspase-9p10 (四) and anti-caspase-3 antibody ( $\square$ ). Protein contents were normalized by probing the same membrane with an anti- $\beta$-actin antibody. The densitometric values of the bands are shown as means with standard deviation indicated by vertical bars, from three independent experiments. Mean values were significantly different from controls (c): ${ }^{\star \star} P<0.01,{ }^{\star \star \star} P<0.001$.

The pre-treatment of both MCF-7 (Fig. 11 (A)) and MDA-MB231 (Fig. 11 (B)) cells with the antagonist was able to reduce the inhibitory effect of AA on the phosphorylation state of ERK1/2 (active form). In addition, in MDA-MB-231 cells the antagonist also reduced the pro-apoptotic effects of AA, as it strongly down regulated Bak expression and augmented procaspase- 3 levels (Fig. 11 (B)).

Taken together, these results indicate that PPAR $\alpha$ may be involved, at least in part, in the growth inhibitory activity of AA on MCF-7 and MDA-MB-231 cells; furthermore,

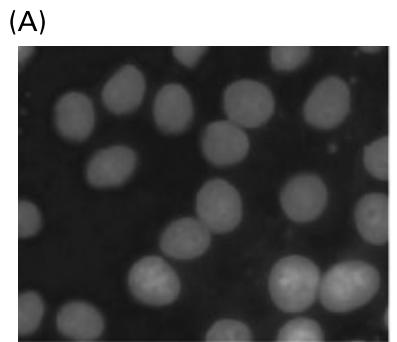

Control

(B)

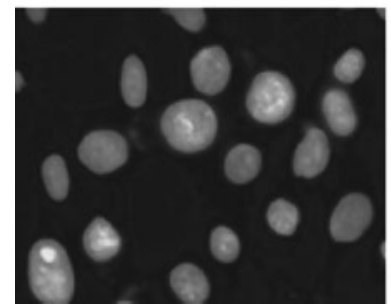

Control

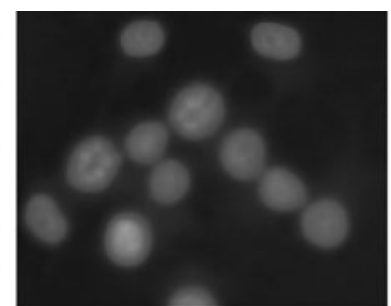

AA $1 \mu \mathrm{M}$

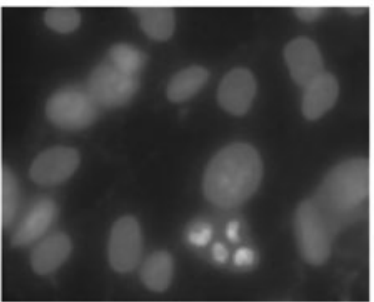

AA $1 \mu \mathrm{M}$

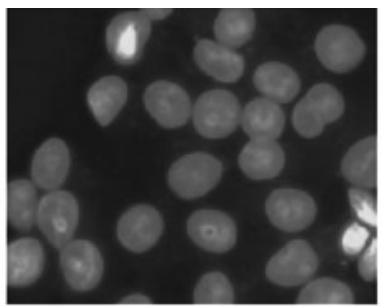

AA $25 \mu \mathrm{M}$

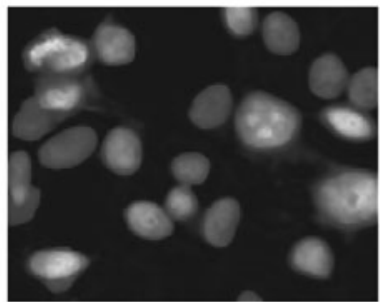

AA $25 \mu \mathrm{M}$

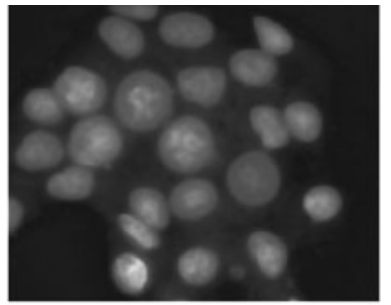

AA $50 \mu \mathrm{m}$

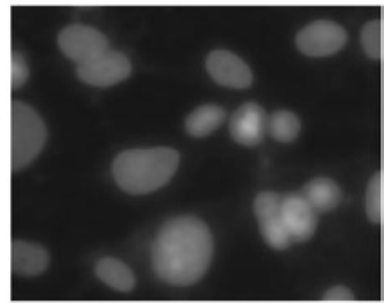

AA $50 \mu \mathrm{M}$

Fig. 5. Effect of arachidonic acid (AA) on nuclear morphology. MCF-7 (A) and MDA-MB-231 (B) breast cancer cells were treated with 1,25 or $50 \mu \mathrm{M}$ AA for $24 \mathrm{~h}$. To detect nuclei the cells were stained with 4',6-diamidino-2-phenylindole $(1 \mathrm{mg} / \mathrm{ml}$ in methanol) and viewed under a fluorescence microscope equipped with a UV light filter. 
(A)

c $\frac{\text { AA } \mu \mathrm{M}}{1 \quad 25 \quad 50}$

pERK1,2

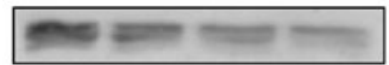

ERK1,2

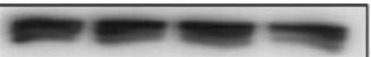

(B)

$\frac{1}{c \quad A A} \frac{4}{c \quad A A} \frac{8}{c \quad A A} \frac{16}{c \quad A A}$

pERK1,

ERK1,2

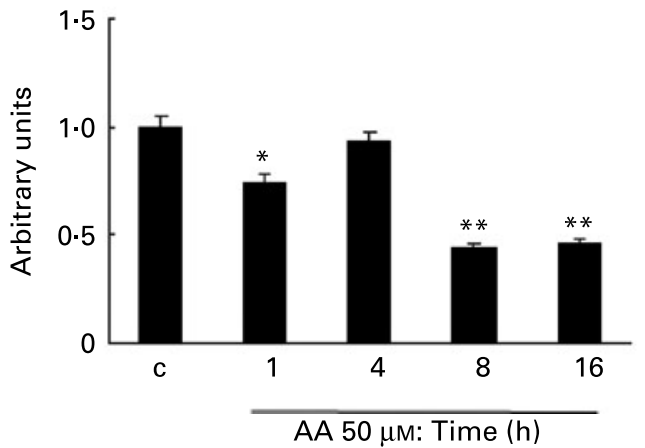

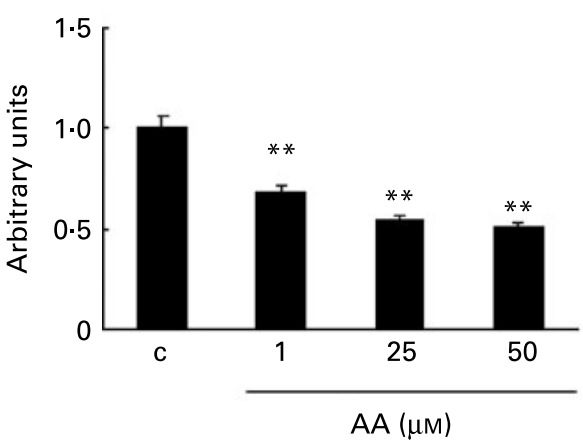

(B)

(A)

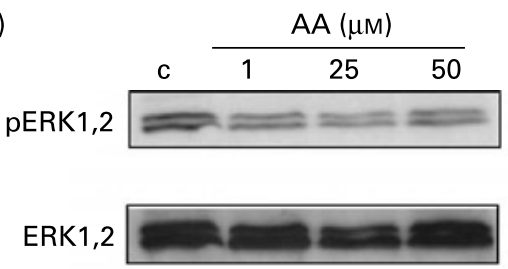

6. Effect of arachidonic acid (AA) on extracellular signal-regulated protein kinase (ERK) $1 / 2$ phosphorylation state in MCF-7 breast cancer cells. MCF-7 cells were incubated with 1, 25 or $50 \mu \mathrm{M}$ AA for $24 \mathrm{~h}$ (A) or with $50 \mu \mathrm{M} \mathrm{AA}$ for $1,4,8$ or $16 \mathrm{~h}$ (B). After treatment, total cell lysates were obtained and probed with an anti-phosphoERK1/2 antibody. Protein contents were normalized by probing the same membrane with an anti-ERK1 antibody. The densitometric values of the bands are shown as means with standard deviation indicated by vertical bars, from three independent experiments. Mean values were significantly different from controls (c): ${ }^{\star} P<0.05,{ }^{*} P<0.01$.
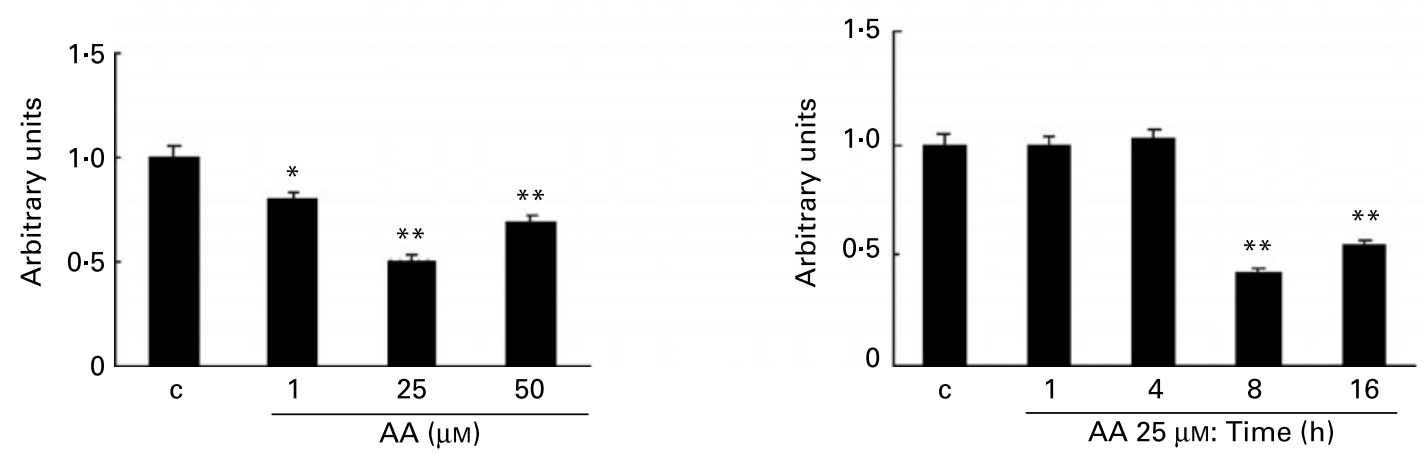

Fig. 7. Effect of arachidonic acid (AA) on the extracellular signal-regulated protein kinase (ERK)1/2 phosphorylation state in MDA-MB-231 breast cancer cells. MDA-MB-231 cells were incubated with 1,25 or $50 \mu \mathrm{M} \mathrm{AA}$ for $24 \mathrm{~h}(\mathrm{~A})$ or with $25 \mu \mathrm{M}$ AA for $1,4,8$ or $16 \mathrm{~h}$ (B). After treatment, total cell lysates were obtained and probed with an anti-phosphoERK1/2 antibody. Protein contents were normalized by probing the same membrane with an anti-ERK1 antibody. The densitometric values of the bands are shown as means with standard deviation indicated by vertical bars, from three independent experiments. Mean values were significantly different from controls (c): ${ }^{\star} P<0.05,{ }^{\star \star} P<0.01$ 
(A)

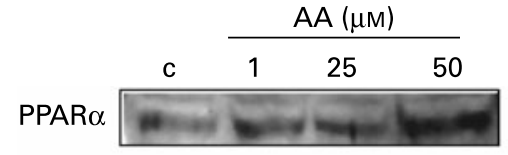

PPAR $\beta$

PPAR $\gamma$

$\beta$-Actin
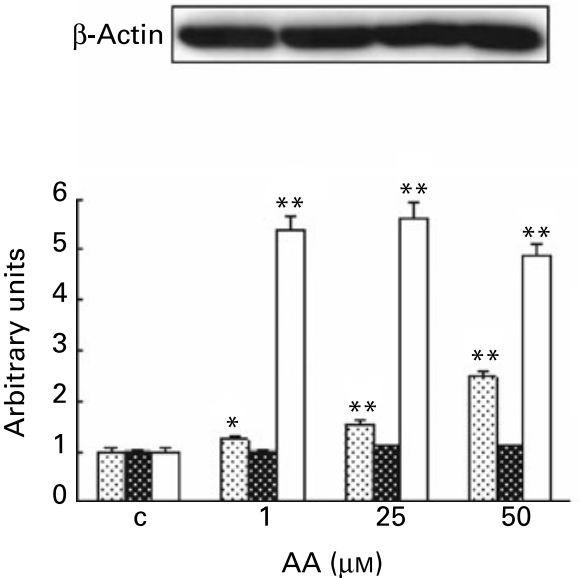

(B)

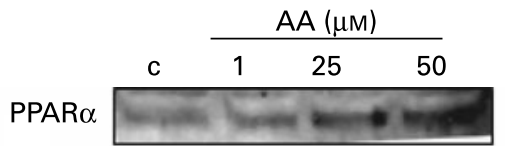

PPAR $\beta$

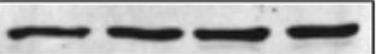

PPAR $\gamma$

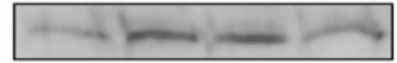

$\beta$-Actin
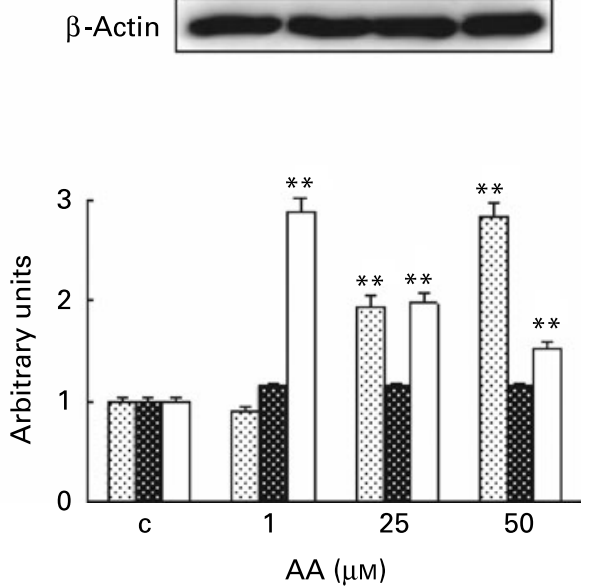

Fig. 8. Effect of arachidonic acid (AA) on PPAR expression. MCF-7 (A) and MDA-MB-231 (B) breast cancer cells were treated with 1, 25 or $50 \mu \mathrm{M}$ AA for $24 \mathrm{~h}$ and total cell lysates were probed with an anti-PPAR $\alpha(\square)$, anti-PPAR $\beta$ (四) and anti-PPAR $\gamma(\square)$ antibody. Protein contents were normalized by probing the same membrane with an anti- $\beta$-actin antibody. The densitometric values of the bands are shown as means with standard deviation indicated by vertical bars, from three independent experiments. Mean values were significantly different from controls (c): ${ }^{*} P<0.05,{ }^{* *} P<0.01$.

(A)
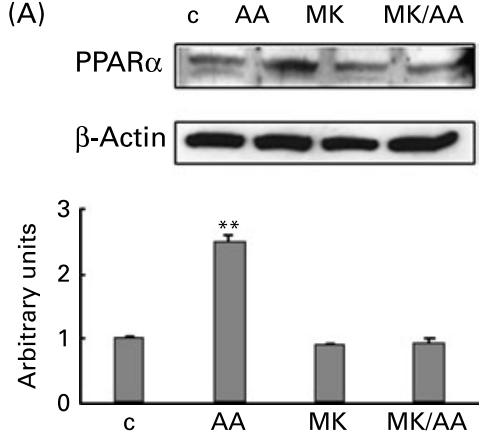

(C)

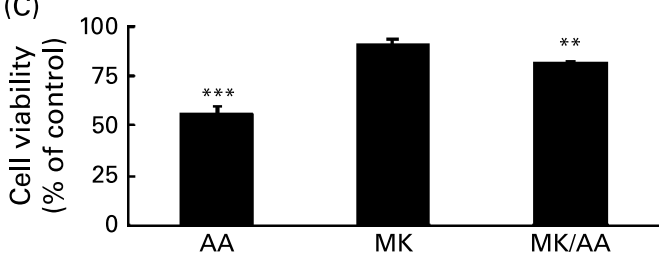

(B)

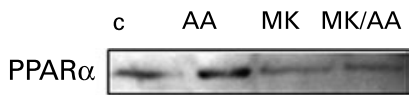

$\beta$-Actin

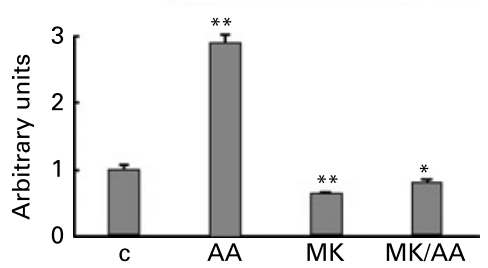

(D)

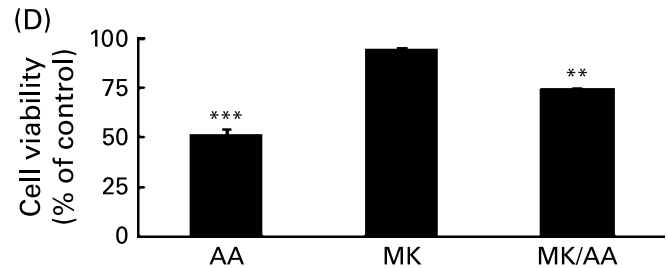

Fig. 9. Effect of arachidonic acid (AA) on cell growth and PPAR $\alpha$ expression in the presence of MK886 (MK). MCF-7 (A, C) and MDA-MB-231 (B, D) breast cancer cells were treated for $24 \mathrm{~h}$ with $50 \mu \mathrm{M}$ AA, $5 \mu \mathrm{M}$ antagonist alone or $5 \mu \mathrm{M}$ antagonist $1 \mathrm{~h}$ before $50 \mu \mathrm{M}$ AA. Total cell lysates were probed with an anti-PPAR $\gamma$ antibody and normalized by probing the same membrane with an anti- $\beta$-actin antibody. In $(A)$ and $(B)$ the densitometric values of the bands are shown as means with standard deviation indicated by vertical bars, from three independent experiments. Mean values were significantly different from controls (c): ${ }^{\star} P<0.05$, ${ }^{* *} P<0.01$. For MCF-7 (C) and MDA-MB-231 (D) cells were treated as described, and cell viability was determined by the trypan blue exclusion test. Values are presented as the percentage of control, as mean values with standard deviation shown by vertical bars, from three independent experiments conducted in triplicate. Mean values were significantly different from controls: ${ }^{\star \star} P<0.01,{ }^{\star \star \star} P<0.001$. 

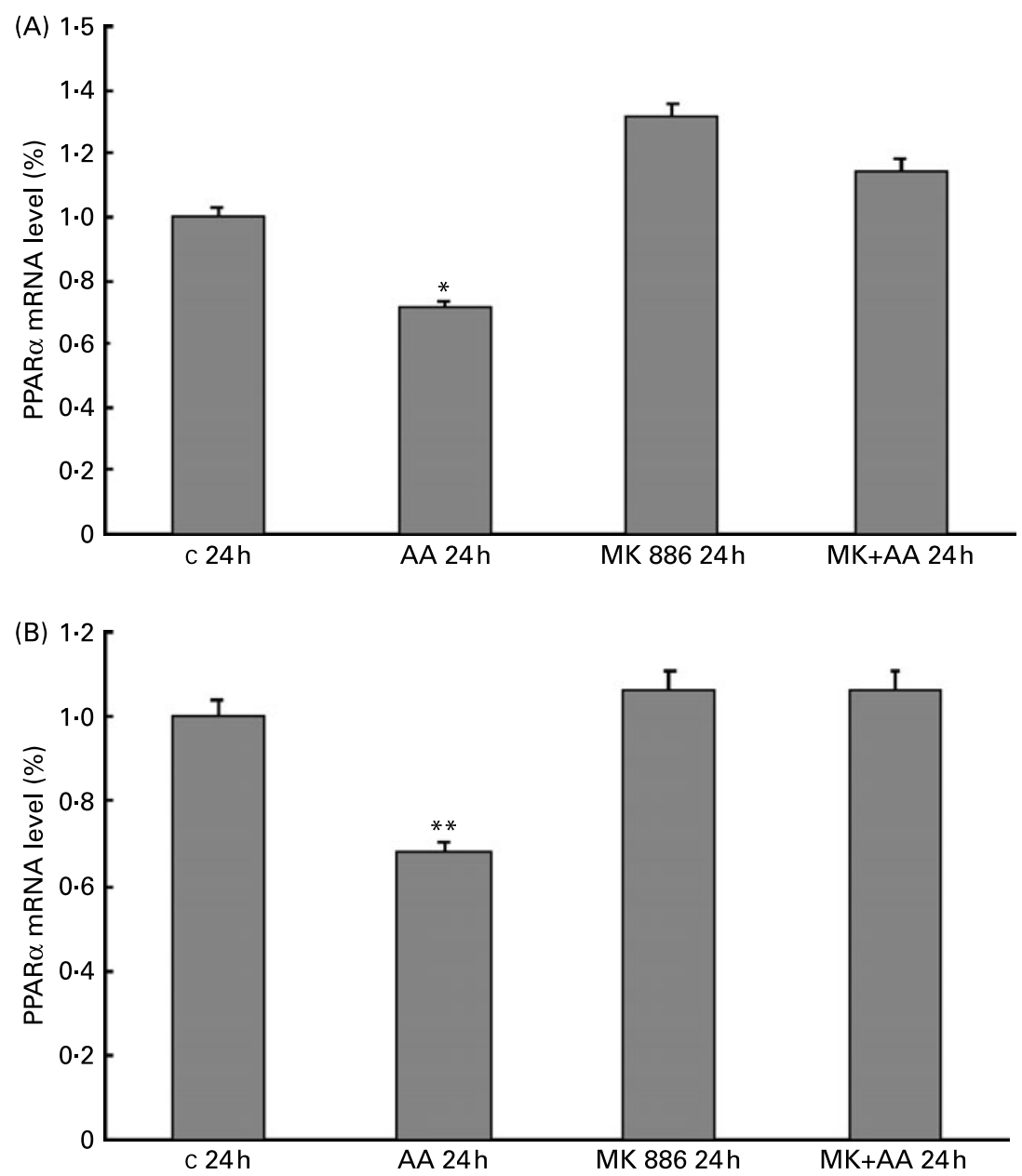

Fig. 10. Effect of arachidonic acid (AA) on PPAR $\alpha$ mRNA expression in the presence of MK886. MCF-7 and MDA-MB-231 breast cancer cells were treated for $24 \mathrm{~h}$ with $50 \mu \mathrm{M} \mathrm{AA}$, with or without $5 \mu \mathrm{M}$ MK886. PPAR $\alpha$ mRNA levels in MCF-7 (A) and MDA-MB-231 (B) cells were determined by real-time PCR. Each sample was tested six times and data are reported as variation calculated taking the values of control cells $(C)$ as 1 . Mean values were significantly different from controls: ${ }^{*} P<0.05,{ }^{* \star} P<0.01$.

in MDA-MB-231 cells, cross-talk between PPAR $\alpha$ induction and signalling pathways involved in the induction of apoptosis may occur.

\section{Discussion}

Breast cancer is one of the most frequently diagnosed cancers and the second most common cause of cancer death in women. Epidemiological and experimental studies conducted over the past few decades suggest a protective role for $n$-3 PUFA against the development of breast and colon cancer $^{(2,3)}$. It has been recently reported that also some $n-6$ PUFA, often believed to exert stimulatory effects on cancer cell growth and metastasis, can reduce the growth of different human breast and colon cancer cells ${ }^{(4)}$.

In this study, we investigated the effects of long-chain polyunsaturated 20:4n-6 AA on $\mathrm{ER} \alpha(+) \mathrm{MCF}-7$ and $\mathrm{ER} \alpha(-)$ MDA-MB-231 human breast cancer cell lines with the aim to elucidate the mechanisms by which AA regulates cell growth.

AA, like other fatty acids, represents a ligand of PPAR, transcription factors belonging to the nuclear hormone receptor super-family that includes receptors for steroids, thyroid hormones, retinoic acid and vitamin $\mathrm{D}^{(28)}$. Increasingly studies have linked PPAR with mammary tumourigenesis ${ }^{(40)}$ and, in particular, PPAR $\gamma$ activators have been trialled as a therapy for breast cancer ${ }^{(41)}$.

PPAR $\gamma$ has an important role in cell growth regulation, differentiation and fat metabolism ${ }^{(28)}$. Recent data have shown that activation of PPAR $\gamma$ causes inhibition of cell proliferation and extensive lipid accumulation ${ }^{(41)}$ in human breast cancer cells that are characterized by high levels of PPAR $\gamma$.

In contrast to the growth-inhibitory effect of PPAR $\gamma$ on breast cancer cells ${ }^{(42)}$, the anti-tumour effect of PPAR $\alpha$ appears to be less commonly reported. One reason for this may be the perception that $\operatorname{PPAR} \alpha$ agonists are carcinogenic in rodents ${ }^{(43)}$ and increase proliferation in some breast cancer cells ${ }^{(44)}$. This tumourigenic effect, however, is controversial as $\operatorname{PPAR} \alpha$ agonists have demonstrated antiproliferative efficacy in vitro against melanoma ${ }^{(45)}$, endometrial and breast cancer cell lines ${ }^{(46)}$.

In our experimental condition AA induces a strong increase in both PPAR $\alpha$ and PPAR $\gamma$ expression, while it does not interfere significantly with PPAR $\beta$ expression. The order of magnitude of this effect differs according to the cell line considered: we detected higher levels of PPAR $\alpha$ in the 
(A)

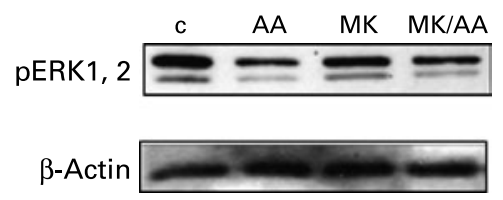

(B)

)
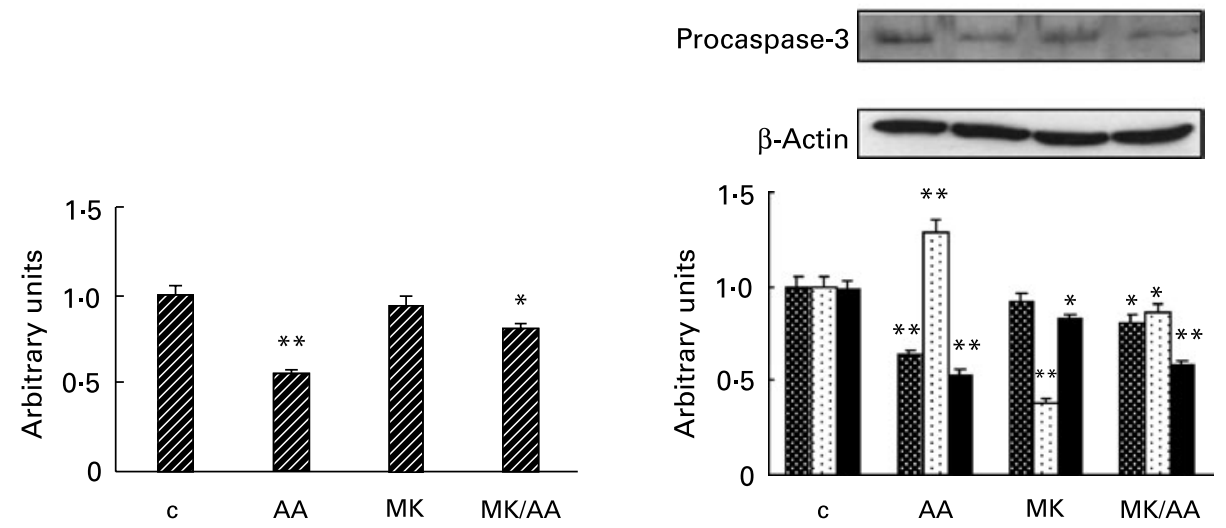

Fig. 11. Effect of arachidonic acid (AA) on phospho-ERK1/2, Bak and procaspase-3 levels in the presence of MK886. MCF-7 (A) and MDA-MB-231 (B) breast cancer cells were incubated for $24 \mathrm{~h}$ with $50 \mu \mathrm{M} A \mathrm{~A}, 5 \mu \mathrm{M}$ antagonist alone or $5 \mu \mathrm{M}$ antagonist $1 \mathrm{~h}$ before $50 \mu \mathrm{M}$ AA and the total cell lysates were probed with an

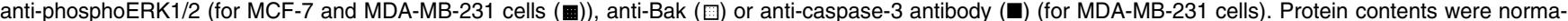
lized by probing the same membrane with anti- $\beta$-actin antibody. The densitometric values of the bands are shown as means with standard deviation indicated by vertical bars, from three independent experiments. Mean values were significantly different from controls $(\mathrm{c}):{ }^{*} P<0.05,{ }^{\star *} P<0.01$.

$\mathrm{ER} \alpha(-)$ MDA-MB-231 than in the ER $\alpha(+)$ MCF-7, while PPAR $\gamma$ was more strongly expressed above all in MCF-7 cells.

These results indicate the involvement of distinct PPAR pathways and are in accordance with studies showing a relationship between the relative levels of PPAR $\alpha$ and ER $\alpha$ in breast cancer cells, where high levels of ER $\alpha$ mRNA expression are associated with reduced levels of PPAR $\alpha^{(47)}$. It has been reported that induction of $\mathrm{ER} \alpha$ expression in MDA-MB-231 cells reduces PPAR $\alpha$ levels whereas inhibition of $\mathrm{ER} \alpha$ activity in $\mathrm{ER} \alpha(+) \mathrm{MCF}-7$ cells increases PPAR $\alpha$ levels $^{(44)}$. These observations suggest that the relationship between $\mathrm{ER} \alpha$ and PPAR $\alpha$ is more than correlative and reflects the ability of ER $\alpha$ to dynamically regulate PPAR $\alpha$ activity and expression ${ }^{(47)}$. The precise relationship between PPAR $\alpha$ and $\mathrm{ER} \alpha$ is not completely elucidated, but studies on PPAR $\alpha$ promoter indicate the presence of at least two nuclear receptor response elements ${ }^{(48)}$ that could potentially be regulated by activated ER $\alpha$.

Although we found that AA induces the expression of both PPAR isotypes in the two cell lines tested, the fact that the PPAR $\alpha$ antagonist completely prevents AA stimulatory effect on PPAR $\alpha$ expression, while the PPAR $\gamma$ antagonist is ineffective, most likely indicates a specific involvement of PPAR $\alpha$ in AA-induced growth inhibition.

PPAR $\alpha$ exerts a dynamic regulation in the mammary gland during pregnancy and lactation and potentially it is hormonally regulated. It is expressed in the mouse mammary gland with the maximum levels at 2 weeks of age and with declining levels during pregnancy and lactation ${ }^{(4)}$, but this potential role of PPAR $\alpha$ may extend beyond the normal physiological regulation of the mammary gland to tumourigenesis $^{(43)}$. Literature data outline various mechanisms to explain the effect of PPAR $\alpha$ in cancer cells; in particular, PPAR $\alpha$ regulates networks involved in the control of cell growth, cell cycle and apoptosis and its agonists probably act through the involvement of the mitogen-activated protein kinase pathway and eicosanoid production ${ }^{(43)}$. In line with these reports, our study showed that in both cell lines treatment with AA produces a reduction of the ERK phosphorylation state, a reduction that was prevented by pre-treatment with PPAR $\alpha$ antagonist MK886. In addition, MK886 was also capable of attenuating AA-mediated cell growth inhibition, while it was notable that, in both cases, pre-treatment with PPAR $\gamma$ antagonist was ineffective.

We showed that AA inhibits the growth of both cell lines in a dose-dependent manner, MDA-MB-231 cells being more sensitive than MCF-7 cells. The growth inhibitory effect of AA is not characterized by alterations in cell cycle progression (data not shown) but is accompanied by different contributions from apoptosis and necrosis. In MDA-MB-231 cells AA growth inhibitory activity is likely related to apoptosis induction. Here again, the PPAR $\alpha$ antagonist was able to prevent AA effects, thus suggesting that the modulation of PPAR $\alpha$ expression contributes to some degree to cell growth inhibition by AA.

Emerging evidence has shown that elevated intracellular AA can induce cell death via the mitochondrial-mediated apoptosis pathway ${ }^{(50)}$. In addition, AA displays pro-apoptotic characteristics such as the ability to be converted to pro-apoptotic eicosanoids ${ }^{(51,52)}$ or to regulate the expression of genes involved in susceptibility and resistance to apoptosis ${ }^{(16)}$.

Collectively, AA shows a different behaviour with regard to cell growth inhibition or cell death induction in correlation with variations in PPAR isotype expression levels. Our results most likely indicate that a PPAR $\gamma$-mediated pathway is not apparently involved in the growth inhibitory activity of AA, whereas a connection can be established with the PPAR $\alpha$ pathway, both in MCF-7 and MDA-MB-231 breast cancer cell lines. The distinct response to AA that we detected could be 
related to the differences between MCF-7 and MDA-MB-231 cells in $\mathrm{ER} \alpha$ levels. Of interest is the observation that the greatest increase of PPAR $\alpha$ protein occurred in ER $\alpha(-)$ MDA-MB-231 cells which underwent induction of apoptosis, in accordance with reports indicating that PPAR $\alpha$ may be correlated to the apoptotic programme execution ${ }^{(29)}$.

These features demonstrate that the 20:4n-6 PUFA, AA, can exert its growth inhibitory activity on breast cancer cells in a similar manner to $n-3$ PUFA, and support the hypothesis that it can be considered also as an anti-tumourigenic compound.

\section{References}

1. Apantaku LM (2000) Breast cancer diagnosis and screening. Am Fam Physician 62, 596-602.

2. Hilakivi-Clarke L, Olivo SE, Shajahan A, Khan G, Zhu Y, Zwart A, Cho E \& Clarke R (2005) Mechanisms mediating the effects of prepubertal (n-3) polyunsaturated fatty acid diet on breast cancer risk in rats. $J$ Nutr 135, 2946S-2952S.

3. Schley PD, Jijon HB, Robinson LE \& Field CJ (2005) Mechanisms of omega-3 fatty acid-induced growth inhibition in MDAMB-231 human breast cancer cells. Breast Cancer Res Treat 92 , 187-195.

4. Hammamieh R, Chakraborty N, Miller SA, Waddy E, Barmada M, Das R, Peel SA, Day AA \& Jett M (2007) Differential effects of omega-3 and omega-6 Fatty acids on gene expression in breast cancer cells. Breast Cancer Res Treat 101, 7-16.

5. Cohen LA (1997) Breast cancer risk in rats fed a diet high in $n-6$ polyunsaturated fatty acids during pregnancy. $J$ Natl Cancer Inst 89, 662-663.

6. Lanson M, Bougnoux P, Besson P, Lansac J, Hubert B, Couet C $\&$ Le Floch O (1990) $n-6$ Polyunsaturated fatty acids in human breast carcinoma phosphatidylethanolamine and early relapse. Br J Cancer 61, 776-778.

7. Wu M, Harvey KA, Ruzmetov N, Welch ZR, Sech L, Jackson K, Stillwell W, Zaloga GP \& Siddiqui RA (2005) Omega-3 polyunsaturated fatty acids attenuate breast cancer growth through activation of a neutral sphingomyelinase-mediated pathway. Int $J$ Cancer 117, 340-348.

8. Monjazeb AM, High KP, Connoy A, Hart LS, Koumenis C \& Chilton FH (2006) Arachidonic acid-induced gene expression in colon cancer cells. Carcinogenesis 27, 1950-1960.

9. Schonberg SA, Rudra PK, Noding R, Skorpen F, Bjerve KS \& Krokan HE (1997) Evidence that changes in Se-glutathione peroxidase levels affect the sensitivity of human tumour cell lines to $n$-3 fatty acids. Carcinogenesis 18, 1897-1904.

10. Sampath H \& Ntambi JM (2005) Polyunsaturated fatty acid regulation of genes of lipid metabolism. Anпи Rev Nutr 25, 317-340.

11. Narayanan BA, Narayanan NK \& Reddy BS (2001) Docosahexaenoic acid regulated genes and transcription factors inducing apoptosis in human colon cancer cells. Int J Oncol 19, 1255-1262.

12. Lands WE (2000) Stories about acyl chains. Biochim Biophys Acta 1483, 1-14.

13. Chilton FH, Fonteh AN, Surette ME, Triggiani M \& Winkler JD (1996) Control of arachidonate levels within inflammatory cells. Biochim Biophys Acta 1299, 1-15.
14. Brash AR (2001) Arachidonic acid as a bioactive molecule. $J$ Clin Invest 107, 1339-1345.

15. Cao Y, Traer E, Zimmerman GA, McIntyre TM \& Prescott SM (1998) Cloning, expression, and chromosomal localization of human long-chain fatty acid-CoA ligase 4 (FACL4). Genomics 49, 327-330.

16. Monjazeb AM, Clay CE, High KP \& Chilton FH (2002) Antineoplastic properties of arachidonic acid and its metabolites. Prostaglandins Leukot Essent Fatty Acids 66, $5-12$.

17. Jurivich DA, Sistonen L, Sarge KD \& Morimoto RI (1994) Arachidonate is a potent modulator of human heat shock gene transcription. Proc Natl Acad Sci U S A 91, 2280-2284.

18. Razanamahefa L, Prouff S \& Bardon S (2000) Stimulatory effect of arachidonic acid on T-47D human breast cancer cell growth is associated with enhancement of cyclin D1 mRNA expression. Nutr Cancer 38, 274-280.

19. Bordin L, Priante G, Musacchio E, Giunco S, Tibaldi E, Clari G \& Baggio B (2003) Arachidonic acid-induced IL-6 expression is mediated by PKC alpha activation in osteoblastic cells. Biochemistry 42, 4485-4491.

20. Wang XJ, Dyson MT, Mondillo C, Patrignani Z, Pignataro O \& Stocco DM (2002) Interaction between arachidonic acid and cAMP signaling pathways enhances steroidogenesis and StAR gene expression in MA-10 Leydig tumour cells. Mol Cell Endocrinol 188, 55-63.

21. Hughes-Fulford M, Chen Y \& Tjandrawinata RR (2001) Fatty acid regulates gene expression and growth of human prostate cancer PC-3 cells. Carcinogenesis 22, 701-707.

22. Bernard-Gallon DJ, Vissac-Sabatier C, Antoine-Vincent D, Rio PG, Maurizis JC, Fustier P \& Bignon YJ (2002) Differential effects of $n-3$ and $n-6$ polyunsaturated fatty acids on BRCA1 and BRCA2 gene expression in breast cell lines. $\mathrm{Br} J$ Nutr 87, 281-289.

23. Jayadev S, Linardic CM \& Hannun YA (1994) Identification of arachidonic acid as a mediator of sphingomyelin hydrolysis in response to tumour necrosis factor alpha. J Biol Chem 269, 5757-5763.

24. Pettus BJ, Bielawska A, Subramanian P, et al. (2004) Ceramide 1-phosphate is a direct activator of cytosolic phospholipase A2. J Biol Chem 279, 11320-11326.

25. Trombetta A, Maggiora M, Martinasso G, Cotogni P, Canuto RA \& Muzio G (2007) Arachidonic and docosahexaenoic acids reduce the growth of A549 human lung-tumour cells increasing lipid peroxidation and PPARs. Chem Biol Interact 165, 239-250.

26. Chinetti G, Fruchart J-C \& Staels B (2000) Peroxisome proliferator-activated receptors (PPARs): nuclear receptors at the crossroads between lipid metabolism and inflammation. Inflamm Res 49, 497-505.

27. Kostadinova R, Wahli W \& Michalik L (2005) PPARs in diseases: control mechanisms of inflammation. Curr Med Chem 12, 2995-3009.

28. Kota BP, Huang TH-W \& Roufogalis BD (2001) An overview on biological mechanisms of PPARs. Pharmacol Res 51, 85-94.

29. Roberts RA, Chevalier S, Hasmall SC, James NH, Cosulich SC $\&$ Macdonald N (2002) PPAR $\alpha$ and the regulation of cell division and apoptosis. Toxicology 181-182, 167-170.

30. Burdick AD, Kim DJ, Peraza MA, Gonzalez FJ \& Peters JM (2006) The role of peroxisome proliferator-activated receptor$\beta / \delta$ in epithelial cell growth and differentiation. Cell Signal 18, 9-20.

31. Li M, Lee TW, Mok TS, Warner TD, Yim AP \& Chen GG (2005) Activation of peroxisome proliferator-activated receptor-gamma by troglitazone (TGZ) inhibits human lung cell growth. J Cell Biochem 96, 760-774. 
32. Bianchi A, Moulin D, Sebillaud S, Koufany M, Galteau MM, Netter P, Terlain B \& Jouzeau JY (2005) Contrasting effects of peroxisome-proliferator-activated receptor (PPAR)gamma agonists on membrane-associated prostaglandin E2 synthase-1 in IL-1beta-stimulated rat chondrocytes: evidence for PPARgamma-independent inhibition by 15-deoxy-Delta12,14prostaglandin $\mathrm{J}_{2}$. Arthritis Res Ther 7, R1325-R1337.

33. Hihi AK, Michalik L \& Wahli W (2002) PPARs: transcriptional effectors of fatty acids and their derivatives. Cell Mol Life Sci 59, 790-798.

34. Kersten S, Desvergne B \& Wahli W (2000) Roles of PPARs in health and disease. Nature 405, 421-424.

35. Clay CE, Namen AM, Atsumi G, Trimboli AJ, Fonteh AN, High KP \& Chilton FH (2001) Magnitude of peroxisome proliferator-activated receptor-gamma activation is associated with important and seemingly opposite biological responses in breast cancer cells. J Investig Med 49, 413-420.

36. Leesnitzer LM, Parks DJ, Bledsoe RK, et al. (2002) Functional consequences of cysteine modification in the ligand binding sites of peroxisome proliferator activated receptors by GW9662. Biochemistry 41, 6640-6650.

37. Kehrer JP, Biswal SS, La E, Thuillier P, Datta K, Fischer SM \& Vanden Heuvel JP (2001) Inhibition of peroxisome-proliferatoractivated receptor (PPAR)alpha by MK886. Biochem J 356, 899-906.

38. Yang X, Stennicke HR, Wang B, Green DR, Janicke RU, Srinivasan A, Seth P, Salvesen GS \& Froelich CJ (1998) Granzyme B mimics apical caspases. Description of a unified pathway for trans-activation of executioner caspase-3 and-7. J Biol Chem 273, 34278-34283.

39. Cimini A, Cristiano L, Colafarina S, Benedetti E, Di Loreto S, Festuccia C, Amicarelli F, Canuto RA \& Ceru MP (2005) PPARgamma-dependent effects of conjugated linoleic acid on the human glioblastoma cell line (ADF). Int $J$ Cancer 117, 923-933.

40. Saez E, Rosenfeld J, Livolsi A, Olson P, Lombardo E, Nelson M, Banayo E, Cardiff RD, Izpisua-Belmonte JC \& Evans RM (2004) PPARgamma signalling exacerbates mammary gland tumour development. Genes Dev 18, 528-540.

41. Burstein HJ, Demetri GD, Mueller E, Sarraf P, Spiegelman BM \& Winer EP (2003) Use of the peroxisome proliferator-activated receptor (PPAR) gamma ligand troglitazone as treatment for refractory breast cancer: a phase II study. Breast Cancer Res Treat 79, 391-397.
42. Mueller E, Sarraf P, Tontonoz P, Evans R, Martin K, Zhang M, Fletcher C, Singer S \& Spiegelman BM (1998) Terminal differentiation of human breast cancer through PPAR $\gamma$. Molecular Cell 1, 465-470.

43. Roberts-Thomson SJ \& Snyderwine EG (2000) Characterization of peroxisome proliferator-activated receptor alpha in normal rat mammary gland and 2-amino-1-methyl-6-phenylimidazo[4,5$b$ ]pyridine-induced mammary gland tumours from rats fed high and low fat diets. Toxicol Lett 118, 79-86.

44. Suchanek KM, May FJ, Robinson JA, Lee WJ, Holman NA, Monteith GR \& Roberts-Thomson SJ (2002) Peroxisome proliferator-activated receptor $\alpha$ in the human breast cancer cell lines MCF-7 and MDA-MB-231. Mol Carcinog 34, 165-171.

45. Grabacka M, Plonka PM, Urbanska K \& Reiss K (2006) Peroxisome proliferator-activated receptor alpha activation decreases metastatic potential of melanoma cells in vitro via down-regulation of Akt. Clin Cancer Res 12, 3028-3036.

46. Saidi SA, Holland CM, Charnock-Jones DS \& Smith SK (2006) In vitro and in vivo effects of the PPAR-alpha agonists fenofibrate and retinoic acid in endometrial cancer. Mol Cancer 5, 13-18.

47. Faddy HM, Robinson JA, Lee WJ, Holman NA, Monteith GR \& Roberts-Thomson SJ (2006) Peroxisome proliferator-activated receptor alpha expression is regulated by estrogen receptor alpha and modulates the response of MCF-7 cells to sodium butyrate. Int J Biochem Cell Biol 38, 255-266.

48. Pineda Torra I, Jamshidi Y, Flavell DM, Fruchart JC \& Staels B (2002) Characterization of the human PPAR $\alpha$ promoter: identification of a functional nuclear receptor response element. $\mathrm{Mol}$ Endocrinol 16, 1013-1028.

49. Master SR, Hartman JL, D'Cruz CM, Moody SE, Keiper EA, Ha SI, Cox JD, Belka GK \& Chodosh LA (2002) Functional microarray analysis of mammary organogenesis reveals a developmental role in adaptive thermogenesis. Mol Endocrinol 16, 1185-1203.

50. Pompeia C, Lima T \& Curi R (2003) Arachidonic acid cytotoxicity: can arachidonic acid be a physiological mediator of cell death? Cell Biochem Funct 21, 97-104.

51. Chen YC, Shen SC \& Tsai SH (2005) Prostaglandin $D_{2}$ and $J_{2}$ induce apoptosis in human leukemia cells via activation of the caspase 3 cascade and production of reactive oxygen species. Biochim Biophys Acta 1743, 291-304.

52. Kwon KJ, Jung YS, Lee SH, Moon CH \& Baik EJ (2005) Arachidonic acid induces neuronal death through lipoxygenase and cytochrome P450 rather than cyclooxygenase. J Neurosci Res 81, 73-84. 